\title{
Pamela Gordon and Denis Harold, eds., Dear Charles Dear Janet: Frame and Brasch in Correspondence
}

\section{Marc Delrez}

\section{(2) OpenEdition \\ 1 Journals}

Electronic version

URL: https://journals.openedition.org/ces/8210

DOI: $10.4000 /$ ces.8210

ISSN: 2534-6695

Publisher

SEPC (Société d'études des pays du Commonwealth)

\section{Printed version}

Date of publication: 1 April 2011

Number of pages: 151-153

ISSN: 2270-0633

\section{Electronic reference}

Marc Delrez, "Pamela Gordon and Denis Harold, eds., Dear Charles Dear Janet: Frame and Brasch in Correspondence", Commonwealth Essays and Studies [Online], 33.2 | 2011, Online since 18 November 2021, connection on 06 January 2022. URL: http://journals.openedition.org/ces/8210 ; DOI: https:// doi.org/10.4000/ces.8210

This text was automatically generated on 6 January 2022 .

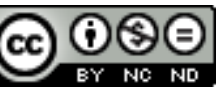

Commonwealth Essays and Studies is licensed under a Licence Creative Commons Attribution - Pas d'Utilisation Commerciale - Pas de Modification 4.0 International. 


\title{
Pamela Gordon and Denis Harold, eds., Dear Charles Dear Janet: Frame and Brasch in Correspondence
}

\author{
Marc Delrez
}

\section{REFERENCES}

Pamela Gordon and Denis Harold, eds. Dear Charles Dear Janet: Frame and Brasch in Correspondence. Auckland: The Holloway Press, 2010. 61 pages. Limited edition of 150 copies. ISBN: 978-0-9864618-0-4. NZ\$250

1 In a letter to Janet Frame (dated 23 February 1966), in which Charles Brasch recommends that Frank Sargeson's papers should be deposited at the Hocken Library under very strict conditions of access, he expresses the following sentiment: "I am appalled at the way people fall like wolves on the letters of writers who are [...] barely in their graves; it's a kind of cannibalism [and] certainly very indecent. I wish one could put a curse on eyes that pry too soon!" (17). Because Frame is known to have left firm instructions that her own letters should be left unseen for as long as possible, as she thought that her work, not her life, belonged in the public domain, this slim volume of correspondence is likely to be as much as we curse-eyed people will get for quite a while. We had better make the most of it, whilst admitting that writers, too, have a right to maintain their privacy, even in posterity. It is hardly surprising that Frame, who so often expressed her horror at the way survivors seize the perspective of deceased people, appointing themselves as their spokespeople and interpreters and thus laying claim to what she calls, in The Rainbirds, "the wisdom of the dead," should have placed her own archive out of bounds in a last - and ultimately respectable attempt to assert authority over the narrative of her life.

2 Yet it is tempting to consider that Frame's letters, which so consistently display her extraordinary stylistic virtues and originality of viewpoint, rightly belong with her 
literary work, and a day will doubtless come when they will be treated as such. This would be in keeping with her avowed determination to consider "the poetry of existence" as primary material to be transmuted and integrated into the literary realm, a transformational vocation to which she remained true whenever she put pen to paper. Thus her initial correspondence with Brasch, purported to be functional since it concerned the submission of a story for publication in Landfall, is astonishing less for its anticipation of rejection than for its unusual form: "You probably won't want it. In that case burn it quickly - quickly - or crush into tinier pieces for Rat Darkness to sneak in and snaffle" (1). Elsewhere, on a more thematic level, she indicates the nature of her response to a friend's death in a way which bears relevance to the commemorative urge implicit in much of her fiction: "We do feed on the dead, just as they feed on us. Who said eating people was wrong?" (54). Perhaps then a form of cannibalism may be authorized after all, for we do feed on Frame, too, those of us who grieve still at the disappearance of this unique writer, in ways that she had uncannily predicted in her more reflexive (and thus personal) texts.

Dear Charles Dear Janet is therefore a most welcome addition to the body of writings by Frame, whilst also lifting a veil from Brasch's thus far unpublished letters and journals. It gives a touching picture of the acquaintance - evolving into friendship - pursued by two beacons of New Zealand literature whose paths first crossed in 1947, and who remained in regular contact, sometimes across hemispheres, until the poet's death in 1973. The portrait which emerges of the latter in particular wonderfully serves the aim of the editors, who wished to pay homage to Brasch on the occasion of the centenary of his birth. He was a noble soul, whose role as a patron of the arts in post-war New Zealand is now well-documented. He tactfully donated portions of his personal fortune to impoverished writers such as Frank Sargeson, James K. Baxter, and possibly others while also providing above-board assistance through his longstanding efforts at the editorial desk of Landfall. Curiously, he was slow at first to perceive Frame's genius, rejecting a story like "Gorse is not People" (for example) on the grounds that her "asylum stories" showed "excessive suffering" (6), but over time his support would become unconditional as well as, in many ways, financial, and his feelings for her grew intense enough to justify some self-censorship. By contrast, it seems at times that Frame had a way of taking him for granted, as in the strangely detached portrait that she pens when first referring to him in her correspondence with Bill Brown. This may have been a reminiscence of her embarrassment that, perhaps as a consequence of Brasch's over-solicitousness, there came a moment when Dunedin hostesses began to include them "as partners in small select dinners" (35). Only his death, apparently, could wholly tame her into acceptance of the part he played in her life, and the concluding pages of the book, in which Frame discovers the intensity of her grief at the loss of this dear friend, strike an elegiac note which is deeply moving. Typically she evokes the poem by W.H. Auden in which he realises "how much closer [...] MacNeice was to him after his death, visiting without being invited but always welcome, and no longer having to be met at the station!" (54-55).

Indubitably the book will be of interest to specialists of New Zealand literature. As a homage to Brasch, it beautifully does its necessary duty. For the Frame aficionado, however, its effect is eventually tantalizing: it contains linguistic gems, and her voice rings most true in those moments when she achieves poetry; but it is frustrating that, by their own admission, "in many cases [the editors] have selected short passages from much longer letters" (60). Also, some imbalance in the correspondence partly explains 
why Frame's perspective was sometimes supplied not via her letters, but by interpolating already familiar passages from her autobiography. Nor are the selected extracts from her letters always a discovery, as some of them had previously been printed in Michael King's biography of the author, Wrestling with the Angel (2000). The frontispiece photograph by Ruth Dallas, showing Charles Brasch, Janet Frame, and C.K. Stead at the former's crib in Broad Bay, Otago Peninsula, in 1966, is similarly familiar from Michael King's work. It is to be hoped that this hand-printed, beautifully designed, but limited and expensive issue will find a way of reaching the public, and that an expanded edition, giving more centrality to Frame's remarkable epistolary voice, can be envisaged when the time is ripe.

\section{AUTHORS}

\section{MARC DELREZ}

Marc DELREZ teaches literature in English (new and established) as well as Comparative Literature at the University of Liège, Belgium. In the post-colonial field, his publications include articles on Salman Rushdie, Randolph Stow, David Malouf, Nicholas Jose, Richard Flanagan, Andrew McGahan, Robert Drewe, and Janet Frame. His monograph on Janet Frame, Manifold Utopia, appeared in Rodopi's Cross/Cultures series. He is currently working on another book on Frame, to be published by Manchester University Press. 